\title{
Exploring Innovation in Northern Canada with Insights from the Mining Innovation System in Greater Sudbury, Ontario
}

\author{
Heather Hall \\ University of Waterloo
}

\begin{abstract}
This article provides an exploratory examination of the innovation dynamics in northern Canada, situated within the broader literature on staples theory, regional development, and regional innovation systems. It uses a case study on the mining innovation system in Greater Sudbury, Ontario-one of the most advanced regional innovation systems in northern Canada-to highlight the importance of innovation support institutions, government intervention, and building on competitive advantages. The article also explores a number of geographic, social, and economic challenges that can hinder entrepreneurship, innovation, and, ultimately, economic development in regions across the North. These include geographic remoteness and isolation, small and often sparsely populated regions, and development approaches that do little to facilitate the reinvestment of resource wealth back into regional development.
\end{abstract}




\section{Introduction}

Innovation-or "the ability to conjure up new products and services, to find novel uses for existing products and to develop new markets" (Independent Panel on Federal Support to Research and Development 2012: E-1) - is seen as paramount for ensuring success and prosperity in the twenty-first century. Given this perception, the topic of innovation has captured the attention of policy makers and researchers across Canada and internationally (see for example Wolfe and Gertler 2016; Independent Panel on Federal Support to Research and Development 2012; European Commission, Joint Research Centre 2016; Conference Board of Canada 2016). The growing body of literature on innovation has offered a number of important insights including the social nature of innovation and the importance of place. However, much of the attention has focused on the experiences of large city-regions (Wolfe 2009), while less is known about innovation in more rural or northern regions. In some instances, such regions are simply ignored in the literature, while in others they are presented as "inauspicious" places (Hall and Donald 2009; Polèse et al. 2002; Johnstone and Haddow 2003; Tödtling and Trippl 2005; Wolfe 2009).

This article provides an exploratory examination of the innovation dynamics in northern Canada, situated within the broader literature on staples theory, regional development, and regional innovation systems. It uses a case study on the mining innovation system in Greater Sudbury, Ontario to provide insights on innovation and economic development in northern regions. This article starts with a discussion of staples theory-a unique Canadian perspective on regional development - and a more recent rendering of the theory that introduces the "resource-bank" approach to development. It then explores some of the key themes in the regional innovation literature with insights for rural and northern contexts. This is followed by a brief discussion on northern Canada, including some of the challenges and opportunities facing regions in the provincial and territorial Norths. The article then focuses on the mining innovation system in Greater Sudbury using a regional innovation systems framework. This includes a discussion of the development of the mining supply and services cluster and the subsystem of regional support institutions and infrastructure. To explore the mining innovation system, this article draws primarily on a review and analysis of secondary data including industry reports and previous research on regional development and innovation in peripheral 
regions. The Sudbury case is then used to provide insights on innovation and economic development in northern regions. This article concludes with a look at some emerging opportunities and recommendations for investment in innovation and regional development across the North.

\section{Staples Theory and Regional Development in Canada}

Staples theory provides a unique understanding of economic development in the Canadian context. The theory was pioneered by Harold Innis (1930) who argued that economic growth in Canada is dependent on the exploitation of raw staples-including fur, fish, timber, minerals, and wheat-that were exported to imperial centres or industrially advanced nations like France, Britain, and the United States (Clement and Williams 1989; Brodie 1997). For Innis, each staple "left its stamp" and was "characterized by specific patterns of settlement, linkages to other economic activities, interactions with the centre, culture and institutional arrangements" (Brodie 1989, 144). Regions become "ensnared" in a"staples trap" characterized by an export mentality, lack of diversification, and large-scale production of low-value, unprocessed staples (Watkins 1963; Barnes 1996; Hayter and Barnes 2001). This makes a region extremely vulnerable to external resource prices and decision making.

Drawing from the work of Innis, Markey et al. (2012) offer a similar framework for understanding the development of contemporary regional development in Canada based on extensive work in Northern British Columbia. They argue that resource-producing regions have developed according to a "logic of exploitation" and, central to this logic, is the "resource-bank approach to development." This approach emphasizes the role of external decision makers (e.g., the provincial government and corporate actors) who exploit or "withdraw" resource assets in resource regions to fund development elsewhere, without adequately investing back into these regions. The effects of this approach have largely intensified since the 1980s, as the regional development priorities of the provincial and federal levels of government have shifted from a postwar focus on spatial inequalities and redistribution to competiveness (see Markey et al. 2008; Hall 2012; Hall and Hodge 2016). At the same time, globalization and new technologies have led to restructuring, including a decline in employment, in many of the resource sectors across the country. This resource-bank approach, coupled with these political and economic shifts, have left many resource-based regions across Canada underdeveloped, often with aging and declining populations, limited employment opportunities, and infrastructure deficits. 


\section{Regional Innovation Systems}

One of the most significant arguments emerging from the innovation literature over the last several decades is that innovation is a social process (Wolfe 2009). It includes a wide variety of stakeholders from individual entrepreneurs, firms, and industry associations, to institutions like government agencies, universities, colleges, and innovation centres. A number of innovation concepts have emerged, since the 1980s, that emphasize this social nature of innovation including industrial districts (Becattini 1990), clusters (Porter 1990), learning regions (Florida 1995; Morgan 1997), triple helix/quadruple helix (Leydesdorff 2012), regional innovation systems (Cooke 1992; Cooke and Morgan 1998), and innovation ecosystems (Independent Panel on Federal Support to Research and Development 2012). The common themes among these concepts include the emphasis placed on interaction and learning between innovation stakeholders (Cooke and Morgan 1998; Morgan 1997; MacKinnon et al. 2002; Asheim et al. 2011; Tödtling and Trippl 2011; Nauwelaers 2011; Rodríguez-Pose 2013), as well as the importance of institutions or "institutional thickness" (Amin and Thrift 1994; 1995), and the "rediscovery" of the "region" (Storper 1997) as the prime site for innovation and learning to occur. This final point emphasizes the distinct place-based assets that influence competitive advantage.

Much of this research, however, has focused on the experiences of large cities in core regions, which "offer diversity and dense concentrations of people, firms, and institutions with global reaches" (Greenwood and Hall 2016, 263; see also Wolfe 2009; Wolfe and Gertler 2016). While this literature does offer important insights, the context in northern and rural regions is often vastly different (see for example Hall and Donald 2009; Hall et al. 2014; Greenwood and Hall 2016; Lagendijk 2011; Tödtling and Trippl 2005; Esparcia 2014; Arbuthnott 2011; Teräs et al. 2015). For example, in their work on innovation in Northern Ontario, Hall and Donald (2009; 2012) describe a number of "peripheral realities." This includes geographic isolation, which is made worse by high transportation costs as well as limited transportation options and infrastructure constraints. Hall and Donald also highlight the prevalence of youth out-migration due to limited economic opportunities, while entrepreneurs can face challenges accessing capital to support their endeavours. Likewise, Tödtling and Trippl (2005) note that institutional thinness is often a characteristic in many peripheral regions, while Lagendijk (2011) explains how older industrial regions

can become locked-in to mature resource-based industries that can stifle learning and innovation. More recent work emerging in Europe and the United Kingdom highlights a number of challenges for sparsely populated 
regions including the difficulty of moving innovation beyond university towns; a lack of critical mass, which can impede entrepreneurialism; and a prevalence of small businesses and large industries with fewer mid-range innovative firms (Teräs et al. 2015).

This article builds on this literature focused on the barriers and realities of economic development and innovation in peripheral regions. It also uses insights from the regional innovation systems literature to explore the mining innovation system in Greater Sudbury. A regional innovation systems approach places emphasis on the social dynamics of innovation and two subsystems of actors: a cluster of firms and the regional support institutions and infrastructure (Cooke et al. 1998; Asheim 2007; Doloreux and Dionne 2008). As Doloreux and Dionne $(2008,261)$ further explain, regional support institutions and infrastructure-or the "institutional thickness" - are central to the regional innovation system, which is made up of three different elements: (1) organizations that promote technology diffusion or generate new entrepreneurial and innovative activities; (2) post-secondary institutions, research organizations, business associations, and other organizations that provide training as well as technical and scientific knowledge; and (3) regional authorities that support regional development. By exploring innovation through this lens, this article provides an exploratory look at the dynamics of innovation in northern Canada.

\section{A Brief Look at Northern Canada}

Northern Canada includes both the provincial North and the territorial North (see Figure 1). Together, this area includes roughly 1.7 million people spread out over 7 million square kilometres, which amounts to roughly $5 \%$ of the Canadian population inhabiting $78 \%$ of Canada's land mass. The provincial North in Canada includes Labrador and the northern regions of the provinces of British Columbia, Alberta, Saskatchewan, Manitoba, Ontario, and Quebec, while the territorial North includes the Yukon, Northwest Territories, and Nunavut. In total, the provincial North has over 1.6 million people, with the largest region being Northern Ontario with a population of 786,000 , while the smallest regions are Northern Saskatchewan $(37,000)$ and Labrador $(27,000)$. The territorial North, on the other hand, has a population of roughly 107,000-this include 35,874 people in the Yukon, 35,944 in Nunavut, and 41,786 in the

Northwest Territories (Hodge, Hall, and Robinson 2016; Statistics Canada 2017). There are a number of small urban areas located across northern Canada; a large number of Indigenous communities; and small, often single-industry resource communities. 
The economy is dominated in many regions by resource extractionespecially forestry, mining, oil, and gas-with minimal value-added production. Much of northern Canada has developed according to the "resource-bank" approach described earlier. For example, Prime Minister Diefenbaker's "Roads to Resources" program, during the late 1950s and early 1960s, was designed to facilitate resource exploration and development through infrastructure in the Yukon and the Northwest Territories (Abele 1987), while regions in the provincial North, like Northern British Columbia and Northern Ontario, have produced vast amounts of mineral and timber resources fueling economic growth and expansion in those provinces (Markey et al. 2012; Ryser et al. 2014). In 2014 , for example, $\$ 11$ billion worth of minerals were produced in Ontario, and much of that was in Northern Ontario (OMA 2015). Yet historically little of this resource wealth has been reinvested back into these regions.

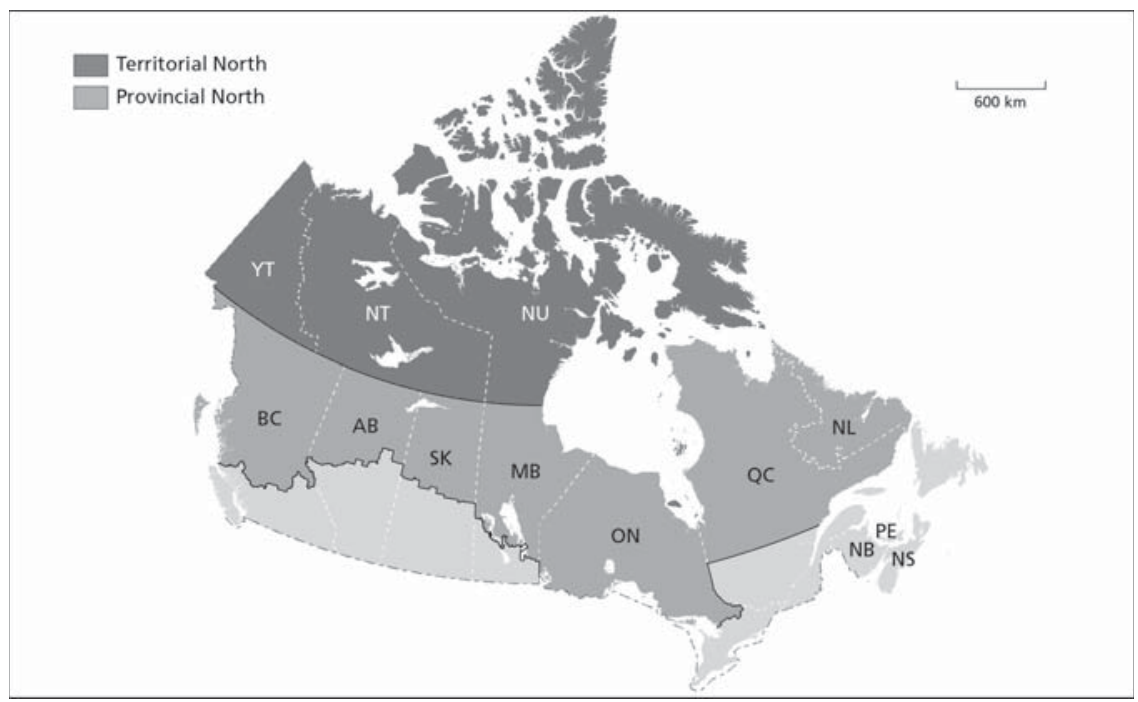

Figure 1. The Canadian North. Source: Hodge, Hall, and Robinson 2016 
This approach to development is changing, however, in Indigenous regions, whereby contemporary treaties, comprehensive land claims agreements, and decisions by the Supreme Court of Canada have provided Indigenous peoples with more control over their traditional territories, and established a Crown duty to consult and accommodate Indigenous peoples (Newman 2014). As a result, a number of arrangements have emerged between government and Indigenous communities, as well as between Indigenous communities and industry, to secure more direct benefits (e.g., royalty revenue, training, and employment) for Indigenous peoples from resource development (Hodge, Hall, and Robinson 2016; Coates and Crowley 2013; Government of Canada 2013). These arrangements, in most instances, do not extend to non-Indigenous communities across the North.

Regions in the provincial North, like Northern Ontario, have no political autonomy. Decision making is largely controlled by provincial policy makers in the southern parts of the provinces (Hall 2012; Markey et al. 2012). In contrast, in the territorial North there has been significant political transformation and the devolution of authority from the federal government to the territorial governments over the last several decades. This includes a number of comprehensive land claims agreements with Indigenous peoples (e.g., in the Yukon); the creation of Nunavut in 1999 as a separate territory for the Inuit; and the 2013 agreement on resource management between the federal government and the Government of Northwest Territories (see Coates 1985; Coates and Poelzer 2014).

Geographic isolation is a reality. In Northern Ontario, for example, there are over thirty communities that have no all-weather roads, a trend that is common across northern Canada (MNDM 2016; INAC 2014). These communities are dependent on winter roads, air, and sometimes water transportation, which increase the cost of living and impacts community development. For example, the cost of food in some communities is double the average when compared to southern regions (Van Dusen 2016; Canadian Press 2016). A number of remote Indigenous communities also face extreme social challenges including poverty, a lack of clean drinking water, and poor housing (Hall and Coates 2017). Access to broadband, cell phone coverage (Hall et al. 2014; Dobby 2016; Louie 2016), and affordable and stable electricity (Coates and Landrie-Parker 2016) are also significant challenges. Many single-industry communities are also facing accelerated population aging caused by lower rates of natural increase and youth 
out-migration leading to population decline (Hodge, Hall, and Robinson 2016; Simms and Ward 2016). Given these challenges, entrepreneurship, innovation, and economic development can be severely inhibited in some communities and regions.

\section{The Mining Innovation System in Greater Sudbury}

The remainder of this article focuses on the development of the mining innovation system in Greater Sudbury to provide insights on innovation and economic development in northern regions. ${ }^{1}$ It is worth noting that Sudbury ${ }^{2}$ is a unique case study to investigate the northern dynamics of innovation in the Canadian context due to its size (population 165,000) and location. As will be discussed later, it is the largest community in northern Canada and is located in the southern part of the provincial North. That being said, the Sudbury case does provide insights into the economic development challenges that are faced by many communities across northern Canada. It also highlights the importance of public investment and infrastructure for enhancing northern innovation. In the circumpolar context, Sudbury is not unlike Oulu (Finland), Tromsø (Norway), and Luleå (Sweden) in terms of its development, size, and function as a regional-service centre. To explore the mining innovation system, this article draws primarily on a review and analysis of secondary data including industry reports. It is also informed by previous research on regional development and innovation in peripheral regions. ${ }^{3}$

\section{A Brief Profile of the City of Greater Sudbury}

The City of Greater Sudbury is located in the symbolic and administrative region of Northern Ontario (see Figure 1). It has a population of 164,689 (Statistics Canada 2017) and is best known as being one of the largest sites of nickel production in the world. Minerals were first discovered in the Sudbury basin in the late 1880s, and by 1971 over 18,000 people were directly employed in the mining industry (Hall 2007). While the current number of people employed directly in the mining industry is much smaller, the city is still known as one of the largest integrated mining sites with roughly 5,600 people employed in nine underground mines, two mills, two smelters, and one nickel refinery (Northern Ontario Business 2016). In 2011, the top industries by labour force included retail trade; health care and social assistance; public administration; and mining, quarrying, and oil and gas extraction (Greater Sudbury n.d.).

Sudbury is the largest community in Northern Ontario, a region with roughly 786,000 people spread out over $90 \%$ of the provincial 
landmass - an area larger than Germany and France combined. The majority of residents live in the five largest communities-Sudbury, Thunder Bay, North Bay, Timmins, and Sault Ste. Marie, while the remainder of the population lives in much smaller, single industry, or Indigenous communities. As the largest city, Sudbury serves as the regional service centre for Northeastern Ontario for government services, healthcare, education, and retail services; a role that emerged through the diversification efforts of local, provincial, and federal stakeholders who were responding to economic restructuring in the mining sector during the late 1970s and early 1980s. The city is home to three post-secondary institutions-Laurentian University, College Boreal, and Cambrian College-as well as the Northern Ontario School of Medicine and the McEwen School of Architecture. A number of federal and provincial government administrative functions were also relocated to Sudbury, including a federal taxation data centre, to offset employment losses in the mining sector and diversify employment opportunities (see Wallace and Thompson 1993; Hall 2007; Hall 2012). As will be discussed in subsequent sections, this relocation also involved a number of government offices related to northern development and mining.

The Development of the Mining Supply and Services Cluster

As noted earlier, the first subsystem of actors in the regional innovation system is the cluster of firms. The mining supply and services cluster in Sudbury was officially recognized in the early 2000s by local economic development officials and through the research of an economist at Laurentian University (Robinson 2005). As Robinson (2005) details, up until that point the possible existence of this cluster was overlooked by local and senior decision makers, for a number of reasons including limited data and a focus on diversification efforts away from the mining sector. However, in 2002 the city's economic development officer highlighted the presence of two to three hundred firms in Sudbury and North Bay that were supplying the mining sector. Subsequent research by Robinson at the Institute for Northern Ontario Research and Development also highlighted the existence of this cluster of firms. Robinson and several other mining experts at Laurentian University were then engaged in developing the city's economic development strategy, and ultimately the mining supply and services cluster became a key engine of economic growth for Sudbury (for a full account see Robinson 2005).

The roots of the cluster, however, started much earlier. During the late 1970s, the major mining companies started downsizing and outsourcing 
services and production due to a number of external economic forces (e.g., increased international competition), labour disputes, and new production technologies. By 1981, the major mining companies had cut approximately 10,000 jobs (Hall 2016; Buse 1993). One positive result of this release of labour was that a number of these unemployed miners, armed with tacit knowledge of the major mining companies, created small and mediumsized enterprises (SMEs) to serve the local mining industry (Robinson 2005; Hall and Donald 2009). There are now 13,500 people working in over 300 mining supply and services companies, which together have generated nearly $\$ 4$ billion in sales in Sudbury (Northern Ontario Business 2016). Their major value creation capabilities include mining engineering and mine management; mining equipment manufacturing; customization of wheeled, tracked, and flanged vehicles; equipment repair and rebuilds; and support (Dyletech Logistics 2010).

\section{Regional Support Institutions}

Another key subsystem of the regional innovation system is the presence of regional support institutions and infrastructure. Local stakeholders often refer to Sudbury as the "Silicon Valley of hard-rock mining" due to the over 400 people who work in mining research and education at Laurentian University, Cambrian College, and College Boreal, and the 250 people who are employed in government ministries with a focus on mining like the Ministry of Northern Development and Mines and the Ontario Geological Survey (Northern Ontario Business 2016). The region is also internationally renowned for its mine rescue training and expertise. As described earlier, Doloreux and Dionne $(2008,261)$ outline three specific elements that provide a useful framework to explore the mining innovation system in Sudbury.

(1) Organizations that promote technology diffusion or generate new entrepreneurial and innovative activities. The Northern Centre for Advanced Technology or NORCAT was established in 1995 at Cambrian College after the founders, Darryl Lake (Cambrian College dean of health, science, trades, and technology) and Glen Crombie (Cambrian College president), travelled to Finland to learn about the experiences of governmentfunded production development and innovation centres. Building on this knowledge, they hoped a technology centre would help stem youth outmigration and assist SMEs in the Sudbury mining sector (Hall and Donald 2009). NORCAT now focuses on three priorities: serving as a regional innovation centre as part of the Ontario Network of Entrepreneurs; developing and providing world-class programs, services, and resources 
to enhance safety and production in the workplace; and operating a vibrant innovation hub. This is accomplished through their innovation mill, which supports and mentors entrepreneurs and SMEs, and through various training programs that are developed and delivered by NORCAT (NORCAT 2016).

(2) Post-secondary institutions, research organizations, business associations, and other organizations that provide training as well as technical and scientific knowledge. There are a number of mining-related education and training programs in Sudbury that contribute to the mining innovation system. These includes the Bharti School of Engineering, the Goodman School of Mines, and the Earth Sciences faculty at Laurentian University; Cambrian College and College Boreal offer a mining engineering technician and technology program, along with other mining-related trades degrees (DeStefano 2015). A number of mining innovation research institutions have also emerged to build on this education and training capacity. For example, the Centre for Excellence in Mining Innovation was created in 2007 at Laurentian University to introduce new practices, procedures, techniques, technologies, and knowledge to improve the performance and safety of the mining industry. They are currently focused on five key areas: FINDMINE, which is focused on improving exploration activities; DEEPMINE, which is centred on reducing the risks of deep mining; VALUEMINE, which examines integrated mine engineering; SUSTAINMINE, which is focused on innovation in environmental performance and social impacts; and BIZMINE, which looks at the business side of the mining industry (CEMI 2016).

Other research institutions include the Mineral Exploration Research Centre (MERC), the Centre for Research in Occupational Safety and Health, the Vale Living with Lakes Centre, and the Mining Innovation Rehabilitation and Applied Research Corporation (MIRARCO). MERC, for example, was created in 1997 to provide research, education, and training on Precambrian ore systems, while MIRARCO was established in 1998 with a mission to develop the people and tools to design and manage the underground mines of the future (Hall and Donald 2009). MIRARCO is now focused on five research domains including geohazard assessment and risk mitigation; mining safety research and risk management; ventilation and production optimization; energy, renewables, and carbon management; and climate adaptation and sustainable communities (MIRARCO 2016). In addition to these mining innovation research institutions, the Sudbury Area Mining Supply and Service Association (SAMSSA) works to promote and maximize the opportunities of SMEs 
in the region, across Canada, and internationally (SAMSSA 2016). Many of these mining innovation support institutions also interact to exchange knowledge, form partnerships, and lobby for the sector (Leeson 2016).

(3) Regional authorities that support regional development. As noted earlier, in an effort to diversify the economy a number of federal and provincial government administrative functions were transferred to Sudbury. One of the most significant initiatives was the 1986 Northern Ontario Relocation Program (NORP), which was a provincial government plan to transfer 1,600 public servants to the region as a tool to help offset employment losses in the mining, forestry, and steel industries (Savoie 1992; Weller 1997; Contenta 1986). The headquarters of the Ministry of Northern Development and Mines, the mining health and safety branch of the Ministry of Labour, and the Ontario Geological Survey were also later moved to Sudbury. By transferring these provincial mining-related research functions to Sudbury, the government was trying to build on the city's mining expertise and establish it as a "centre of mining excellence" (Sudol 2004). One local stakeholder described it as "the most successful regional development strategy in Northern Ontario over the last 50 years" (Key Informant in Hall and Donald 2009).

There are also government regional development agencies like the Northern Ontario Heritage Fund Corporation (Ontario Government) and FedNor (Government of Canada) that provide funding for entrepreneurship, innovation, and research and development (NOHFC 2016; FedNor 2016). Entrepreneurs across Northern Ontario describe these agencies as "a lifeline" for levelling the playing field in terms of access to capital (Hall and Donald 2009). The provincial government also shows its support through other initiatives. For example, the Minister of Northern Development and Mines recently hosted a Mining Innovation Summit in Sudbury to discuss emerging trends in the mining sector with key stakeholders (Gravelle 2016). At the local level, mining innovation is a cornerstone of the economic development strategy for the City of Greater Sudbury (City of Greater Sudbury Community Development Corporation 2015), and a recent branding strategy is marketing the city as Canada's "Resourceful City," building on Sudbury's rich mining history and perseverance. 


\section{Reflecting on Innovation in Northern Canada}

The Sudbury case offers a number of important insights for understanding the dynamics of innovation in northern Canada, including the importance of critical mass and relative location, building on competitive advantages, and government intervention. To begin with, as the largest community in the Canadian North, Sudbury offers the natural amenities often associated with the North (e.g., space, access to lakes and forests), but it is also a regional service centre with a population of 165,000 people. Lepawsky et al. (2010) use the term "metropolis on the margin" to describe places like Sudbury that are peripheral in terms of location and perhaps political decision making, but offer urban amenities and the critical mass for economic development. Related to this is its relative location. While Sudbury is considered "northern" in the Ontario provincial context, its location is quite south when compared to the rest of northern Canada. It also benefits from infrastructure connections (e.g., road, rail, and air) to international hubs like Toronto that are comparatively cheaper. In contrast, geographic isolation is a reality for many communities in northern Canada, with often limited infrastructure and extremely costly transportation options.

Another important component of the Sudbury case is the untraded interdependencies or place-based assets related to its long industrial history tied to the mineral sector. As noted earlier, mining has been a significant economic driver in Sudbury for over 120 years. While the major mining companies provide fewer direct employment opportunities, they are still in operation and they also provide the major market for many of the mining supply and services companies (Dyletech 2010). The longevity of the mining sector and the presence of these anchor firms, therefore, provides more certainty for entrepreneurial ventures. In addition, there is a deep understanding or tacit knowledge of the industry, which spans across multiple generations in some families (Hall 2016). On the other hand, many smaller resource communities across northern Canada have experienced downsizing or the closure of their major industries. In these instances, many workers have chosen to relocate or commute for new employment opportunities due to the economic uncertainty and limited employment opportunities (Ryser et al. 2016). In many Indigenous communities in northern Canada, there is also a different history and focus tied to more formal entrepreneurship and economic development (see Walker 2009; BNCE 2016), and this requires more research to understand the dynamics of innovation in such communities. 
The Sudbury case also emphasizes the importance of "institutional thickness" including the high number of institutions related to mining innovation. Related to this is the role of public institutions in supporting innovation in peripheral regions. For example, in their work on La Pocatière, Quebec, Doloreux and Dionne (2008) discuss the significant role public institutions had in encouraging firm innovation in this rural community. Likewise, Oughton et al. (2002: 98) argue that there is a comparatively greater need for public spending on innovation in so-called lagging regions. As highlighted in the Sudbury case study, government investment, and the relocation of government administration functions along with public research institutes, have been instrumental in supporting the mining innovation system. While institutional thickness has historically been weaker across northern Canada, this is changing. There are three colleges in the territorial North and a much larger number of colleges, research institutes, and universities in the provincial Norths. A number of innovation centres are also emerging including the Cold Climate Innovation Centre and the Centre for Northern Innovation in Mining at Yukon College. In addition, the federal government created the Canadian Northern Economic Development Agency (CanNor) for the Territorial North. These public institutions are playing a stronger role in supporting and facilitating new research and economic development on pressing northern challenges. However, policy makers also need to be aware of what Oughton et al. $(2002,98)$ term the "regional innovation paradox" or "the comparatively greater need to spend on innovation in lagging regions and their relatively lower capacity to absorb public funds earmarked for the promotion of innovation and to invest in innovation related activities." Essentially, there is a disconnect between the supply of innovation support, including funding, and the demand for these supports. To confront this paradox, absorptive capacity needs to be increased, along with stronger interaction between regional support infrastructure and firms to identify areas of demand.

Sudbury is also challenged by the "resource-bank approach to development" where very little of the resource wealth that is extracted in the region is reinvested back, especially for advancing the mining sector in terms of value-added production. In addition, much of the innovation and research in the mining supply and services sector in Sudbury is "focussed on backward linkages, which are there to facilitate the extraction not necessarily to facilitate value-added" (Key Informant in Hall 2012). This fuels the Innis argument of the staples trap or a "rip-it-out-and-ship-itout" mentality that is pervasive across Canada. Richard Hawkins (2012), 
in a report exploring innovation from a uniquely Canadian perspective, argues that by exporting unprocessed or semi-processed products like minerals, we are also exporting most of the opportunities to innovate, opportunities for sustainable employment, and opportunities for business spinoffs. Equally concerning from a firm-level perspective in the mining supply and services cluster, is the home market sales concentration and dependency on one or two customers (Dyletech 2010). 'This is in contrast to the importance of "global pipelines and local buzz" (Bathelt et al. 2004), which is often stressed in the innovation literature-or the importance of firm-level external linkages beyond the region as well as local interactions that promote the exchange of knowledge. As a result, Sudbury is still prone to the effects of the boom and bust nature of the resource economy, which impacts demographic growth, economic diversification, and overall community sustainability.

\section{Discussion and Conclusions}

Regions across northern Canada face a number of geographic, social, and economic challenges that can hinder entrepreneurship, innovation, and ultimately economic development. Geographic remoteness and isolation, small and often sparsely populated regions, and development approaches that do little to facilitate the reinvestment of resource wealth into regional development are especially problematic. However, examples like the mining innovation system in Greater Sudbury highlight the importance of innovation support institutions, government intervention, and building on competitive advantages.

Across northern Canada, there are a number of positive trends on the horizon that could be harnessed to enhance development and innovation on pressing challenges. These include the political and economic empowerment of Indigenous peoples in northern communities. Resource benefit agreements, for example, are securing greater benefits, while the growth of Indigenous economic development corporations are supporting entrepreneurs and business development. There are potential opportunities here to partner on initiatives that could adapt science and technology for the North, but also grow the regional innovation system across northern Canada. As described by Hall, Leader, and Coates (2017), more research is needed to identify examples of innovation and the relationship between industry, research institutes, universities, colleges, and government agencies in promoting scientific and technological innovations in northern regions. 
To fully realize the innovation potential across northern Canada, senior levels of government need to be more strategic, especially with regard to resource development. As Markey et al. (2012) argue, we need development approaches that focus on investing in northern communities versus approaches that simply view them as sites of resource extraction. One idea in Northern Ontario that has been advocated by local stakeholders for years is to take a portion of the royalties made from resource extraction and reinvest them back into research and development at northern universities and colleges (Hall 2012). This approach is being used in other regions across the country, like in Newfoundland and Labrador where regulations set by the federalprovincial offshore petroleum board require oil and gas producers to spend a certain percentage of their revenues on research and development (R\&D) as well as on education and training in that province (Greenwood and Hall 2016).

Some regions across northern Canada could also benefit from having an innovation strategy much like the smart specialization approach that has captured the attention of policy makers across Europe and the United Kingdom (see Healy, 2017). While some aspects of the smart specialization approach might be unattainable in the Canadian context, the process is worthy of more attention. At the very least, having strategic economic development plans could help local stakeholders identify priorities for research and public investment. As noted earlier, simply having more public spending on innovation in peripheral regions is not enough without an increase in the absorptive capacity of these regions to harness this support. Having a plan is one tool that can increase capacity and facilitate stronger interaction between innovation stakeholders.

\section{Author}

Heather Hall is an assistant professor in the School of Environment, Enterprise and Development (SEED) at the University of Waterloo in Ontario.

\section{Acknowledgements}

The author would like to thank the participants at the Circumpolar Innovation Workshop in Whitehorse, Yukon for their comments on an earlier version of this paper. This paper is also informed by previous research from the following research projects: "Innovation and Creativity in Northern Ontario" (Hall and Donald 2009; 2012); 
"Stuck Between a Rock and a Hard Place: The Politics of Regional Development Initiatives in Northern Ontario" (Hall 2012); "Advancing Innovation in Newfoundland and Labrador" (Hall and Walsh 2013); and "Social Dynamics of Economic Performance in City-Regions" (Greenwood and Hall 2016).

\section{Notes}

1. This is an exploratory case study on the development of the innovation system and the subsystems of actors. More up-to-date empirical research is needed on how collaboration occurs between these actors and to what extent, as well as the knowledge spillovers leading to new opportunities in other sectors.

2. While the formal name is Greater Sudbury, the city is commonly referred to as Sudbury.

3. This includes primary data from interviews with mining innovation support institutions and firms from a study exploring Innovation and Creativity in Northern Ontario (Hall and Donald 2009; 2012); an extensive account of regional economic development in northern Ontario from Stuck Between a Rock and a Hard Place: The Politics of Regional Development Initiatives in Northern Ontario (Hall 2012); and literature insights on innovation in rural and peripheral regions from the Advancing Innovation in Newfoundland and Labrador project (Hall and Walsh 2013). The author has also engaged in a number of discussion forums and meetings on innovation in Sudbury as well as across northern Canada and the Circumpolar North through her activities with the University of the Arctic's Thematic Network on the Commercialization of Science and Technology for the North.

\section{References}

Abele, F. 1987. "Canadian Contradictions: Forty Years of Northern Political Development." Arctic 40(4): 310-320.

Amin, A., and N. Thrift. 1994. "Living in the Global." In Globalization, Institutions, and Regional Development in Europe, edited by A. Amin and N. Thrift, 1-22. Oxford: Oxford University Press.

Amin, A., and N. Thrift. 1995. "Institutional Issues for the European Regions: From Markets and Plans to Socioeconomics and Powers of Association." Economy and Society 24(1): 41-66.

Arbuthnott, A. 2011. "Regional Cooperative and Competitive Forces Driving Industry Cluster Development and Renewal in the Swedish Periphery." Journal of Rural and Community Development 6(1): 22-48.

Asheim, B., 2007. "Differentiated Knowledge Bases and Varieties of Regional Innovation Systems." Innovation 20(3): 223-241. 
Asheim, A., R. Boschma, and P. Cooke. 2011. "Constructing Regional Advantage: Platform Policies Based on Related Variety and Differentiated Knowledge Bases." Regional Studies 45(7): 893-904. https://doi.org/10.1080/00343404.2010 .543126

BNCE. 2016. “Building Northern Capacity Through Entrepreneurship.” University of Saskatchewan. https://northerncapacity.com.

Barnes, T.J. 1996. “External Shocks: Regional Implications of an Open Staple Economy." In Canada and the Global Economy: The Geography of Structural and Technological Change, edited by J.N.H. Britton, 48-68. Montreal and Kingston: McGill-Queen's University Press.

Bathelt, H., A. Malmberg, and P. Maskell. 2004. "Clusters and Knowledge: Local Buzz, Global Pipelines and the Process of Knowledge Creation." Progress in Human Geography 28(1): 31-56.

Becattini, G. 1990. “The Marshallian Industrial District as a Socio-Economic Notion. In Industrial Districts and Inter-firm Co-operation in Italy, edited by P. Pyke, G. Becattini, and W. Sengenberger, 37-51. Geneva: International Institute for Labour Studies (ILO).

Brodie, J. 1989. “The Political Economy of Regionalism.” In The New Political Economy, edited by W. Clement and G. Williams, 136-159. Montreal: McGillQueen's University Press.

Brodie, J. 1997. “The New Political Economy of Regions.” In Understanding Canada: Building on the New Canadian Political Economy, edited by W. Clement, 249-270. Montreal: McGill-Queen's University Press.

Buse, D.K. 1993. “The 1970s." In Sudbury: Rail Town to Regional Capital, edited by C.M. Wallace and A. Thomson, 242-274. Toronto: Dundurn Press Ltd.

Canadian Press. 2016. Northern Ontario Reserve Residents Spend Over Half of Income on Food: Report. The Toronto Star, September 12. https://www.thestar. com/news/canada/2016/09/12/northern-ontario-reserve-residents-spendover-half-of-income-on-food-report.html.

CEMI. 2016. "About CEMI." https://www.miningexcellence.ca/?page id=693.

City of Greater Sudbury Community Development Corporation. 2015. "From the Ground Up-2015-2025." http://www.investsudbury.ca/ftgu.pdf.

Clement, W., and G. Williams. 1989. "Introduction." In The New Political Economy edited by W. Clement and G. Williams, 3-15. Montreal: McGill-Queen's University Press.

Coates, K. 1985. Canada's Colonies: A History of the Yukon and Northwest Territories. Toronto: James Lorimer \& Company.

Coates, K., and B.L. Crowley. 2013. "New Beginnings: How Canada's Natural Resource Wealth Could Re-Shape Relations with Aboriginal People." Aboriginal Canada and the Natural Resource Economy Series. Ottawa: MacdonaldLaurier Institute. 
Coates, K., and G. Poelzer. 2014. An Unfinished Nation: Completing the Devolution Revolution in Canada's North. Ottawa: Macdonald-Laurier Institute.

Coates, K., and D. Landrie-Parker. 2016. Northern Indigenous Peoples E The Prospects for Nuclear Energy. Saskatoon: International Centre for Northern Governance and Development.

Conference Board of Canada. 2016. Innovation-How Canada Performs. http:// www.conferenceboard.ca/hcp/details/innovation.aspx.

Contenta, S. 1986. "Premier Unveils Plan to Transfer 290 Public Servants to Sudbury." Toronto Star, July 30: A1.

Cooke, P. 1992. "Regional Innovation Systems: Competitive Regulation in the New Europe. Geoforum 23(3): 365-382.

Cooke, P. 1998. "Introduction: Origins of the Concept." In Regional Innovation Systems: Yhe Role of Governance in a Globalized World, edited by H. Braczyk, P. Cooke and M. Heidenreich, 2-25. London: UCL Press.

Cooke, P., and K. Morgan. 1998. The Associational Economy: Firms, Regions, and Innovation. Oxford: Oxford University Press.

Dobby, C. 2016. "CRTC Faces Hard Truths About Internet Access in Canada's North." The Globe and Mail, April 11. http://www.theglobeandmail.com/reporton-business/crtc-faces-hard-truths-about-internet-access-in-canadas-north/ article29597669/.

Doloreux, D., and S. Dionne. 2008. “Is Regional Innovation System Development Possible in Peripheral Regions? Some Evidence from the Case of La Pocatière, Canada." Entrepreneurship and Regional Development 20(3): 259-283.

Dyletech Logistics. 2010. Northern Ontario Mining Supply and Services Study. Prepared for the Ontario North Economic Development Corporation.

European Commission, Joint Research Centre. 2016. "Smart Specialisation Platform." http://s3platform.jrc.ec.europa.eu.

Esparcia, J. 2014. "Innovation and Networks in Rural Areas. An Analysis from European Innovative Projects." Journal of Rural Studies 34: 1-14. https://doi. org/10.1016/j.jrurstud.2013.12.004

FedNor. 2016. "FedNor. Government of Canada." http://fednor.gc.ca/eic/site/ fednor-fednor.nsf/eng/Home.

Florida, R. 1995. “Toward the Learning Region." Futures 27(5): 527-536.

Foray, D., J. Goddard, X. Goenaga Beldarrain, M. Landabaso, P. McCann, K. Morgan, C. Nauwelaers, and R. Ortega-Argiles. 2012. Guide to Research and Innovation Strategies for Smart Specialisations (RIS 3). Luxembourg: European Commission.

Government of Canada. 2013. Agreements Between Mining Companies and Aboriginal Communities or Governments. Ottawa: Natural Resources Canada.

Gravelle, M. 2016. “Ontario Leading Way in Mining Innovation: Gravelle.” The Sudbury Star, November 1. http://www.thesudburystar.com/2016/11/01/ ontario-leading-way-in-mining-innovation-gravelle. 
Greater Sudbury. n.d. "Labour Force by Industry Division." http://www. greatersudbury.ca/sudburyen/assets/File/Website Labour\%20Force \%20 by $\% 20$ Industry $\% 20$ Division.pdf

Greenwood, R., and H.M. Hall. 2016. "The Social Dynamics of Economic Performance in St. John's: A Metropolis on the Margins." In Growing Urban Economies: Innovation, Creativity, and Governance in Canadian City-Regions, edited by D.A. Wolfe and M.S. Gertler, 363-388. Toronto: University of Toronto Press.

Hall, H.M. 2007. Being Realistic About Planning in No Growth Communities: Challenges, Opportunities, and Foundations for a New Agenda in the Greater Sudbury, CMA. M.A. Thesis, University of Waterloo.

Hall, H.M. 2012. "Stuck Between a Rock and a Hard Place: The Politics of Regional Development Initiatives in Northern Ontario." PhD Diss., Department of Geography, Queen's University, Kingston.

Hall, H.M. 2016. "Exploring the Nature, Extent, and Community Impacts and Responses to E-RGM in Long Harbour Newfoundland and Labrador and Sudbury Ontario." Extractive Industries and Society 3(3): 606-615. https://doi. org/10.1016/j.exis.2016.06.003

Hall, H.M., and K. Coates. 2017. "Missed Opportunities, Glimmers of Hope: Aboriginal Communities and Mineral Development in Northern Ontario." Aboriginal Canada and the Natural Resource Economy Series. Ottawa: Macdonald-Laurier Institute. http://www.macdonaldlaurier.ca/how-toreignite-the-ring-of-fire-and-mining-in-northern-ontario-mli-paper-byheather-hall-and-ken-coates/

Hall, H.M., J. Leader, and K. Coates. 2017. “Introduction: Building a Circumpolar Innovation Agenda." The Northern Review 45: 3-10. https://doi.org/10.22584/ $\underline{\text { nr45.2017.001 }}$

Hall, H.M., and B. Donald. 2009. Innovation and Creativity on the Periphery: Challenges and Opportunities in Northern Ontario. Working Paper Series: Ontario in the Creative Age. REF. 2009-WPONT-002.

Hall, H.M., and B. Donald. 2012. “Clarifying Creativity and Culture in a Small City on the Canadian Periphery: Challenges and Opportunities in Greater Sudbury." In Cultural Political Economy of Small Cities, edited by A. Lorentzen and B. van Heur, 80-94. London: Routledge.

Hall, H.M., and G. Hodge. 2016. "The Death and Life of Regional Planning in Canada." Plan Canada 56(3): 32-35.

Hall, H.M., and J. Walsh. 2013. Advancing Innovation in Newfoundland and Labrador: Knowledge Synthesis. St. John's: Harris Centre. http://innovationnl.ca/wpcontent/uploads/2013/08/Advancing-Innovation-Knowledge-Synthesis.pdf.

Hall, H., J. Walsh, K. Vodden, and R. Greenwood. 2014. Challenges, Opportunities, and Strategies for Advancing Innovation in Newfoundland and Labrador.Final Report of the Advancing Innovation in Newfoundland and Labrador Project. St. John's: Harris Centre. 
Hayter, R., and T.J. Barnes. 2001. "Canada's Resource Economy." The Canadian Geographer 45(1): 36-41.

Hawkins, R. 2012. Looking at Innovation from a Uniquely Canadian Perspective: The Case for a New Alliance of Practice, Policy and Scholarship. Discussion Paper, Innovation. Ottawa: Institute for Science, Society and Policy, University of Ottawa.

Healy, A. 2017. "Innovation in Circumpolar Regions: New Challenges for Smart Specialization." The Northern Review 45: 11-32. https://doi.org/10.22584/ $\underline{\text { nr45.2017.002 }}$

Hodge, G., H.M. Hall, and I.M. Robinson. 2016. Planning Canadian Regions $2^{\text {nd }}$ Edition. Vancouver: UBC Press.

INAC. 2014. “Ontario Region. Government of Canada.” www.aadnc-aandc.gc.ca/ eng/1100100020284/1100100020288\#ft4a.

Independent Panel on Federal Support to Research and Development. 2012. Innovation Canada: A Call to Action. Review of Federal Support to Research and Development - Expert Panel Report. Ottawa: Government of Canada.

Innis, H.A. 1930. The Fur Trade in Canada: An Introduction to Canadian Economic History. London: H. Milford Oxford University Press.

Johnstone, H., and R. Haddow. 2003. "Industrial Decline and High Technology Renewal in Cape Breton: Exploring the Limits of the Possible." In Clusters Old and New: The Transition to a Knowledge Economic in Canada's Regions, edited by D.A. Wolfe, 187-212. Montreal \& Kingston: McGill-Queen's University Press.

Lagendijk, A. 2011. "Regional Innovation Policy Between Theory and Practice." In Handbook of Regional Innovation and Growth, edited by P. Cooke, with B. Asheim, R. Boschma, R. Martin, D Schwartz, and F. Tödtling, 597-608. Cheltenham: Edward Elgar.

Leeson,B.2016. “LaurentianCreatesSudburyResearchHub.” TheSudburyStar,Feb20.http:// www.thesudburystar.com/2016/02/20/laurentian-creates-sudbury-research-hub.

Lepawsky, J., C. Phan, and R. Greenwood. 2010. "Metropolis on the Margin: Talent Attraction and Retention to the St. John's City-Region." The Canadian Geographer 54(3): 324-46. https://doi.org/10.1111/j.1541-0064.2010.00315.x

Leydesdorff, L. 2012. “The Triple Helix, Quadruple Helix, ..., and an N-Tuple of Helices: Explanatory Models for Analyzing the Knowledge-Based Economy?" Journal of the Knowledge Economy 3(1): 25-35. https://doi.org/10.1007/ $\underline{\text { s13132-011-0049-4 }}$

Louie, R. 2016. "High-Speed Broadband is Essential for Rural and Northern Canada." Federation of Canadian Municipalities. http://www.fcm.ca/home/ media/news-and-commentary/2016/high-speed-broadband-is-essential-forrural-and-northern-canada.htm.

Markey, S., G. Halseth, and D. Manson. 2008. "Challenging the Inevitability of Rural Decline: Advancing the Policy of Place in Northern British Columbia." Journal of Rural Studies 24(4): 409-421. 
Markey, S., G. Halseth, and D. Manson. 2012. Investing in Place: Economic Renewal in Northern British Columbia. Vancouver: UBC Press.

MacKinnon, D., A. Cumbers, and K. Chapman. 2002. “Learning, Innovation and Regional Development: A Critical Appraisal of Recent Debates." Progress in Human Geography 26(3): 293-311.

MIRARCO. 2016. “About.” http://www.mirarco.org/about/

MNDM. 2016. Northern Ontario Winter Roads. Northern DevelopmentTransportation Support. www.mndm.gov.on.ca/en/northern-development/ transportation-support/northern-ontario-winter-roads

Morgan, K. 1997. "The Learning Region: Institutions, Innovation and Regional Renewal." Regional Studies 31(5): 491-503.

Nauwelaers, C. 2011. "Intermediaries in Regional Innovation Systems: Role and Challenges for Policy." In Handbook of Regional Innovation and Growth, edited by P. Cooke, with B. Asheim, R. Boschma, R. Martin, D Schwartz, and F. Tödtling, 467-481. Cheltenham: Edward Elgar.

Newman, Dwight. 2014. Revisiting the Duty to Consult Aboriginal Peoples. Saskatoon: Purich Publishing.

NOHFC. 2016. "Programs - Ontario's Economic Future Points North!” http:// nohfc.ca/en/programs.

Northern Ontario Business. 2016. “Cluster Report Overlooks Sudbury's Mining Cluster: MP." Northern Ontario Business, July 6. https://www.northernontariobusiness.com/ industry-news/mining/cluster-report-overlooks-sudburys-mining-cluster-mp-372104.

NORCAT. 2016. "About NORCAT.” http://www.norcat.org/about-norcat/.

OMA. 2015. "Facts and Figures." http://www.oma.on.ca/en/ontariomining/facts figures.asp.

Ontario Chamber of Commerce. 2016. “The Ring of Fire." http://www.occ.ca/ issue/ring-of-fire/.

Oughton, C., M. Landabaso, and K. Morgan. 2002. "The Regional Innovation Paradox: Innovation Policy and Industrial Policy." The Journal of Technology Transfer 27(1): 97-110.

Polèse, M., R. Shearmur, P.M. Desjardins, and M. Johnson. 2002. The Periphery in the Knowledge Economy: The Spatial Dynamics of the Canadian Economy and the Future of Non-Metropolitan Regions in Quebec and the Atlantic Provinces. Montreal and Moncton: Institut national de la recherche scientfiique and the Canadian Institute for Research on Regional Development.

Porter, M.E. 1990. The Competitive Advantage of Nations. New York: Free Press.

Robinson, D.R. 2005. "Sudbury's Mining Supply and Service Industry: From a Cluster 'In Itself' to a Cluster 'For Itself'." In Global Networks and Local Linkages: The Paradox of Cluster Development in an Open Economy, edited by David A. Wolfe \& Matthew Lucas, 155-176. Kingston: McGill-Queen's University Press. 
Rodríguez-Pose, A. 2013. “Do Institutions Matter for Regional Development?” Regional Studies 47(7): 1034-1047. https://doi.org/10.1080/00343404.2012.7489 $\underline{78}$

Ross, I. 2016. "Toronto Think-Tank's Industry Cluster Model Excludes Mining." Northern Ontario Business, July 5. https://www.northernontariobusiness.com/industry-news/ mining/toronto-think-tanks-industry-cluster-model-excludes-mining-372098.

Ryser, L., S. Markey, D. Manson, and G. Halseth. 2014. "From Boom and Bust to Regional Waves: Development Patterns in the Peace River Region, British Columbia." Journal of Rural and Community Development 9(1): 87-111.

Ryser, L., S. Markey, and G. Halseth. 2016. “The Workers' Perspective: The Impacts of Long Distance Labour Commuting in a Northern Canadian Small Town." The Extractive Industries and Society 3(3): 594-605. https://doi.org/10.1016/j. exis.2016.02.002

SAMSSA. 2016. "About SAMSSA." http://samssa.ca/about/.

Savoie, D. 1992. Regional Economic Development: Canada's Search for Solutions (2 ${ }^{\text {nd }}$ Edition). Toronto: University of Toronto Press.

Simms, A., and J. Ward. 2016. Regional Population Projections for Labrador and the Northern Peninsula 2016-2036. Report prepared for The Harris Centre for Regional Development and Policy, Memorial University Population Project: Newfoundland and Labrador in Transition. St. John's: Harris Centre Regional Analytics Laboratory (RAnLab), Memorial University.

Statistics Canada. 2017. "Census Profile, 2016 Census." Catalogue no. 98-316X2016001. http://www12.statcan.gc.ca/census-recensement/2016/dp-pd/prof/ index.cfm?Lang=E

Storper, M. 1997. The Regional World: Territorial Development in a Global Economy. New York: Guilford Press.

Sudol, S. 2004. "Grits Peterson was North's Best Friend." The Sudbury Star, February 20: A9.

Teräs, J., A. Dubois, J. Sörvik, and M. Pertoldi. 2015. Implementing Smart Specialisation in Sparsely Populated Areas. JRC Technical Reports. S3 Working Papers Series, No. 10/2015.

Tödtling, F., and F. Tripple. 2005. “One Size Fits All? Towards a Differentiated Regional Innovation Policy Approach.” Research Policy 34: 1203-1219.

Tödtling, F., and M. Trippl. 2011. Regional Innovation Systems. In Handbook of Regional Innovation and Growth, edited by P. Cooke, with B. Asheim, R. Boschma, R. Martin, D Schwartz, and F. Tödtling, 455-466. Cheltenham: Edward Elgar.

Van Dusen, J. 2016. “Nunavut, Northwest Territories Food Insecurity Reaches Record Level: Study." CBC News, April 8. http://www.cbc.ca/news/canada/north/ food-insecurity-reaches-record-level-nunavut-northwest-territories-1.3523105.

Wallace, C.M., and A. Thomson. 1993. Sudbury: Rail Town to Regional Capital. Toronto: Dundurn Press Ltd. 
Walker, K. 2009. Northern Entrepreneurship. Prepared for the International Institute for Sustainable Development (IISD) and the International Centre for Governance and Development.

Watkins, M.H. 1963. "A Staples Theory of Economic Growth." The Canadian Journal of Economics and Political Science 29(2): 141-158.

Weller, G.R. 1997. "Politics and Policy in the North." In The Government and Politics of Ontario ( ${ }^{\text {th }}$ Edition), edited by G. White, 284-306. Toronto: University of Toronto Press.

Wolfe, D.A. 2009. 21st Century Cities in Canada: The Geography of Innovation. The 2009 CIBC Scholar-in-Residence Lecture. Ottawa: Conference Board of Canada.

Wolfe, D.A., and M.S. Gertler. 2016. Growing Urban Economies: Innovation, Creativity, and Governance in Canadian City-Regions. Toronto: University of Toronto Press. 